

\title{
Fatwa Role in Education and Legal Dispute in Malaysia
}

\author{
Wan Mohd Khairul Firdaus Wan Khairuldin
}

To Link this Article: http://dx.doi.org/10.6007/IJARPED/v7-i4/4978

DOI: $10.6007 /$ IJARPED/v7-i4/4978

Received: 21 Oct 2018, Revised: 30 Nov 2018, Accepted: 13 Dec 2018

Published Online: 15 Dec 2018

In-Text Citation: (Khairuldin, 2018)

To Cite this Article: Khairuldin, W. M. K. F. W. (2018). Fatwa Role in Education and Legal Dispute in Malaysia. International Journal of Academic Research in Progressive Education and Development, 7(4), $295-302$.

Copyright: (C) 2018 The Author(s)

Published by Human Resource Management Academic Research Society (www.hrmars.com)

This article is published under the Creative Commons Attribution (CC BY 4.0) license. Anyone may reproduce, distribute, translate and create derivative works of this article (for both commercial and non-commercial purposes), subject to full attribution to the original publication and authors. The full terms of this license may be seen at: http://creativecommons.org/licences/by/4.0/legalcode

Vol. 7, No. 4, 2018, Pg. 295 - 302

http://hrmars.com/index.php/pages/detail/IJARPED

JOURNAL HOMEPAGE

Full Terms \& Conditions of access and use can be found at http://hrmars.com/index.php/pages/detail/publication-ethics 


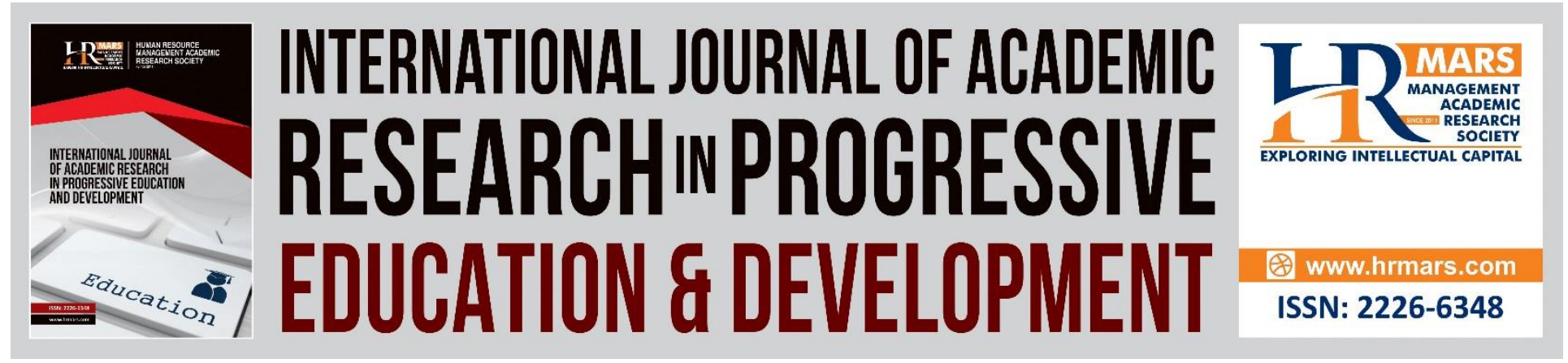

\title{
Fatwa Role in Education and Legal Dispute in Malaysia
}

\author{
Wan Mohd Khairul Firdaus Wan Khairuldin \\ Faculty of Islamic Contemporary Studies, Universiti Sultan Zainal Abidin, \\ Terengganu. Malaysia \\ Email : wanfirdaus@unisza.edu.my
}

\begin{abstract}
Fatwa is the legal answer to address the current issues arising from the community. Fatwa plays an important role in the development of Islamic law. Fatwa institutions in Malaysia serve as a medium of dissemination of information in addressing the problems and confusion faced by Muslims. Any information relating to fatwa will affect the will of the individual, society and organization. Various new issues arise to the requirement of fatwa in finding solutions that coincide with the reality of society today. But how is the role played by the fatwa institution in issuing a legal decision? Hence, this article will discuss the role of fatwa in disseminating information and to see how far the fatwa can educate the society in solving the problems that arise.
\end{abstract}

Keywords: Fatwa, dissemination

\section{INTRODUCTION}

Fatwa in terms of language originates from the word ifta 'ifta'an which means explanation or answer by someone who is faqih about something that concerns him or has legal ambiguity (Usamah Umar al-Ashqarm, 2009). Fatwa in terms of istilah is defined as the answer put forward by the mufti on the matters that occurred when asked the question on it. According to the Islamic Encyclopedia, fatwa is a decision of religious law made with reference to the Quran, hadiths and other sources of law including ijtihad by mufti or those who have the right to make decisions regarding Islamic law (Malaysian Encyclopedia Research Center, 1998). It explains that the position of the fatwa is to explain to the public on the issues arising whether the legal response is solely by mufti or jointly by the Fatwa Committee or the Shariah Committee (Gadut, 2006).

Fatwas among the community today is really important since the society is always faced with various issues and problems according to the current needs, situations and places. By referring to the fatwa, the legal issues can be solved according to the rules of Islam and fatwas are seen to educate the society by providing guidance, advice and teaching. However, today's 
Vol. 7, No. 4, 2018, E-ISSN: 2226-6348 @ 2018 HRMARS

world development has led people to face the changing times that require them to make decisions related to religious law. In fact, the public is exposed to various information dissemination or the law that cannot be ascertained. This will lead to discrepancies in information and they tend to make mistakes related to religion.

Therefore, the community needs a medium of dissemination of information that has proven its validity to be used as a reference to solve all the problems. Such information should be properly disseminated by authorized sources or qualified persons in the relevant field. Every answer issued by the mufti in particular should be communicated to the public so that they are not exposed to confusion. In the event of confusion in the process of understanding the fatwa that has been issued, the problem cannot be resolved due to the misunderstanding in understanding the fatwas issued.

\section{METHODOLOGY}

This article used documentation method to get a clear picture of a fatwa role in educational society about hukm and information. Classical and contemporary works were referred to complete the data collection for this study. Results from data collection were then analysed using content analysis method. Content analysis was used to examine and explain the interpretations in the documents. According to Krippendorff (2004) and Rohana Yusof (2004), analysis of contents is a research technique by making conclusions systematically and objectively through data in the document form.

\section{ANALYSIS}

Various legal issues that take place require a procedure or method of settlement which should be disseminated by authorized sources in the field of law enforcement. The dissemination of fatwa information must be channeled through various media so that it can provide appropriate knowledge and explanation to the community (Wan Zulkifli et.al, 2014).

According to Zulkifli et al. (2014), there are several factors that encourage the responsible party in issuing a fatwa. Among them are the queries to the public, government agencies or organizations. In addition, the fatwa may be issued if it receives instructions from the government, its own initiative and other factors such as spontaneous reviews and answers to a dispute (Wan Zulkifli et al. 2014).

\section{The use of social media as a medium of disseminating fatwa information}

Social media is a kind of medium of information delivery that has the features of openness, community, conversation and so on that helps people interact in various ways (Azman Md Zain et.al, 2018). The use of social media in conveying information, such as web pages, you tube, email, facebook, instagram and so forth is seen as a way or content in spreading information quickly, easily and effectively. In the context of fatwa dissemination in Malaysia, fatwa institutions are not left behind to utilize the use of social media in delivering fatwa and legal clarification in line with today's technological advances. Among the social media forms used are as follows: 


\section{1. e-SMAF Portal}

The al-Ahkam al-Fiqhyah Information Resource Portal (e-SMAF) is an official website introduced by the Department of Islamic Development Malaysia (JAKIM). This e-SMAF portal contains fatwa and legal views covering all aspects such as the aspect of akidah, ibadah, munakahat, muamalat and so on. This portal allows people to access legal and fatwa decisions issued by all states in Malaysia. This portal brings convenience to the public as it contains the latest fatwa and legal views besides providing a legal question called Legal Felo. Legal Felo are a matter of legal responsibility that provides answers from JAKIM-appointed experts on current issues posed by the community.

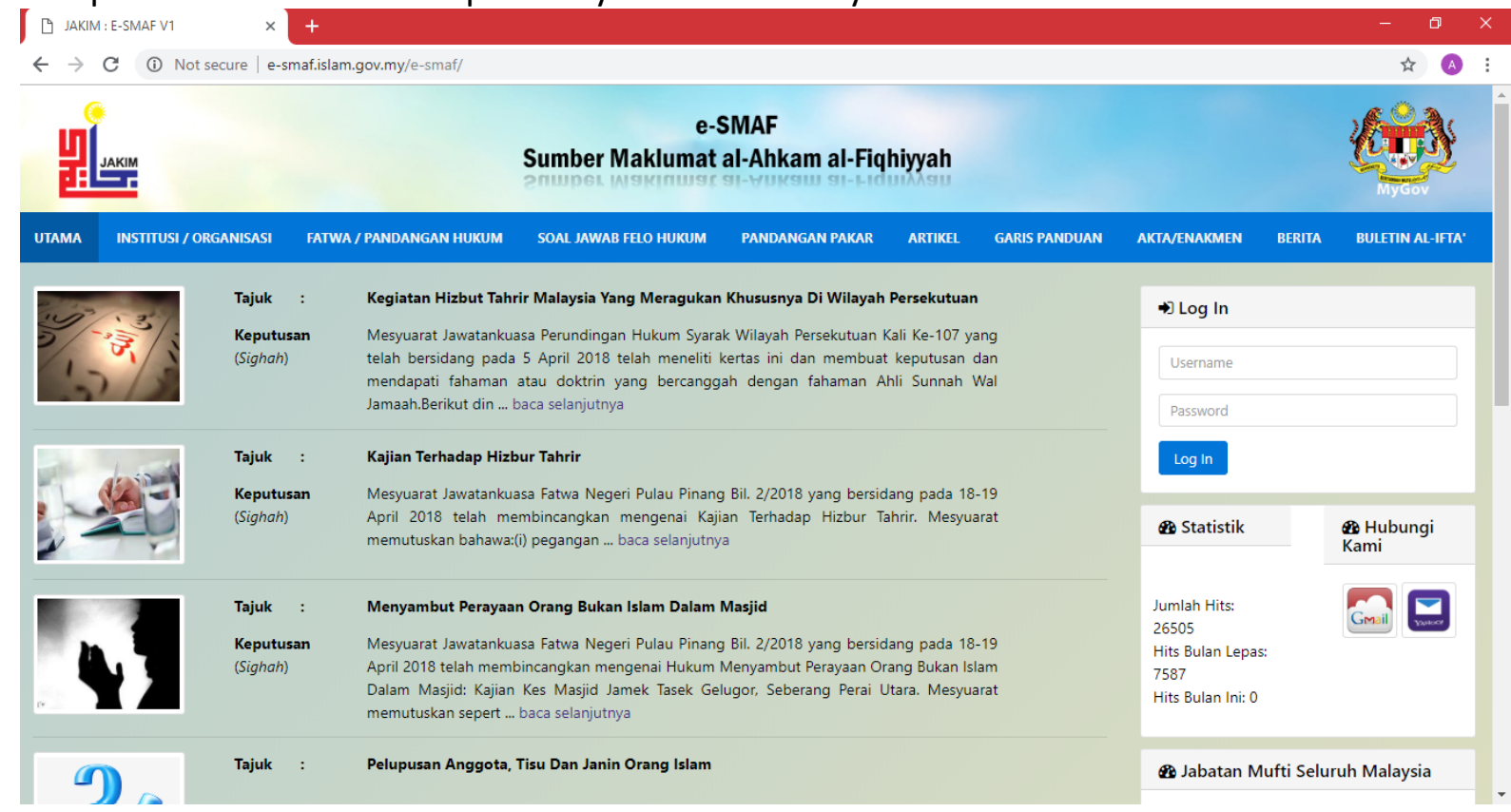

\section{The e-fatwa system}

Figure 1: Portal e-SMAF

The e-fatwa system is one of the initiatives introduced by the Mufti of Federal Territory in 2018. The system aims to facilitate references to the public on gazetted fatwa. E-fatwa is one of the best and fastest solutions for the community because of its convenient, friendly, upto-date and reliable facilities. Therefore, the e-fatwa system needs to be maintained and enhanced by better management. According to a study conducted by Najwa (2006), all mufti departments in Malaysia are currently using the e-fatwa system as one of the mediums in disseminating their fatwa.

The use of e-fatwa gives the public an opportunity to ask questions about the law for any problem. This system is not only available in Malaysia but it is also used by other countries. This system covers all the fatwa that has been issued whether the fatwa is gazetted or not gazetted. According to Noor et. al (2008) in his study found that the e-fatwa system became the best solution to the community as its use was in line with today's technological advancement and is a credible reference because it can be accessed quickly and easily. The diagram below shows the site of the e-fatwa system found in Malaysia. 
INTERNATIONAL JOURNAL OF ACADEMIC RESEARCH IN PROGRESSIVE EDUCATION AND DEVELOPMENT

Vol. 7, No. 4, 2018, E-ISSN: 2226-6348 @ 2018 HRMARS

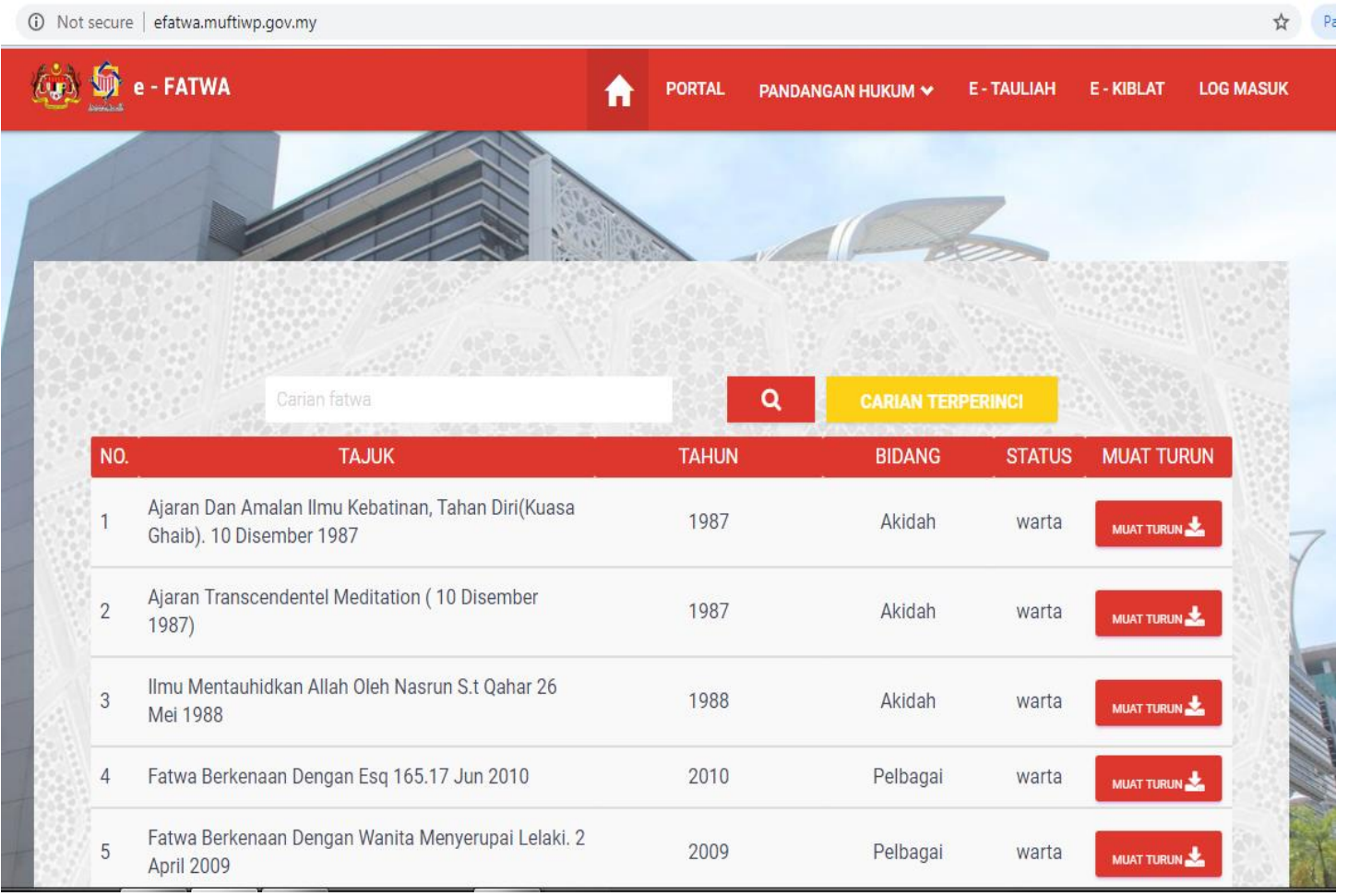

Figure 2: e-FATWA system in Malaysia

In addition, the Mufti Department in Malaysia also uses social media approaches in delivering or providing fatwa information to the public as it can provide space for the community to directly interact with the mufti department in asking the questions regarding the fatwa issued. This medium is a clear sign of the importance of social media as a medium of rapid information dissemination (Zain et.al, 2018). The diagram below is an example of the use of media used for the purpose of distributing fatwa.

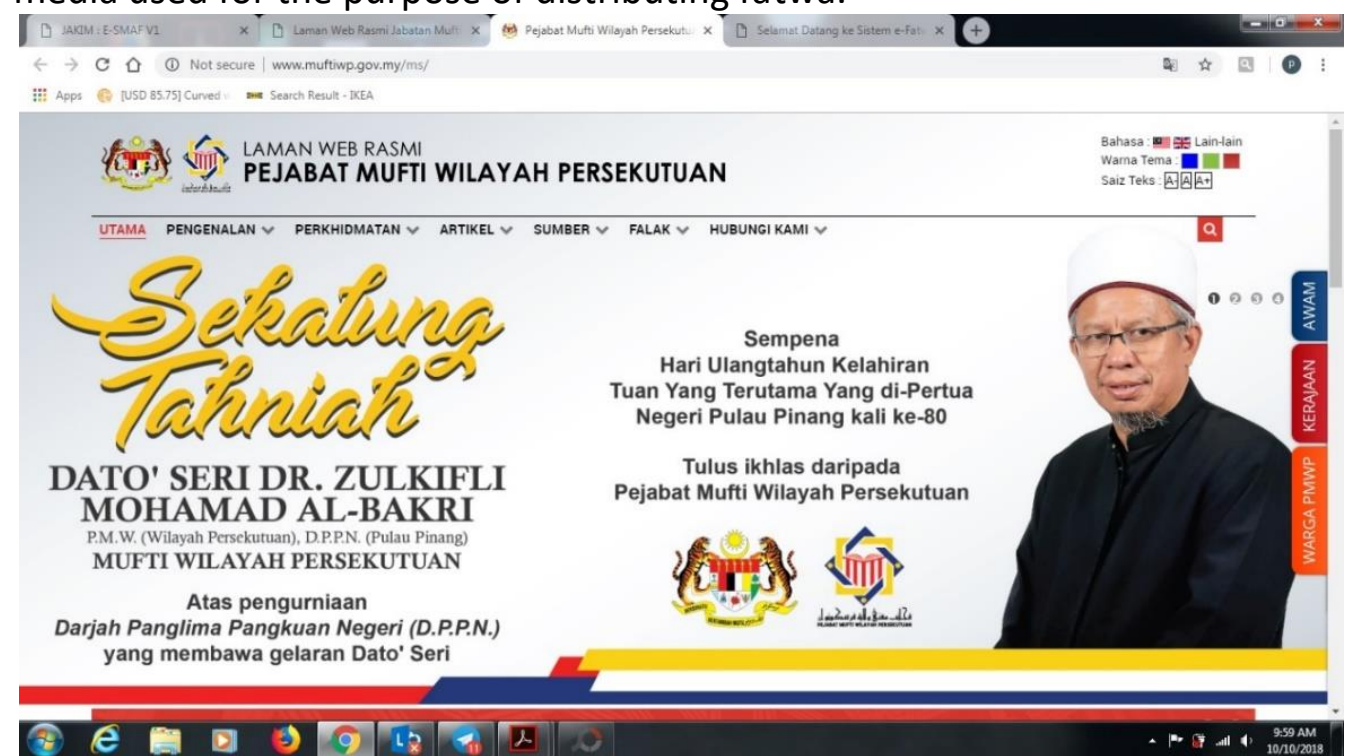

Figure 3: Mufti of Federal Territory Mufti Official Website 


\section{Publishing}

In addition to the use of social media as a medium of dissemination of fatwa, fatwa institutions comprising JAKIM, Mufti Department, mufti and so forth also published several forms of writing. Among them are books, pamphlets, magazines, pamphlets, reports, reading materials and explanations related to religious law. Apart from social media and printed media, verbal or mufti writing is also one of the mediums of fatwa dissemination. Each form of mass media in the dissemination of fatwa plays a distinctive role in helping the party responsible for spreading the religious law. (Yusof, 2011).

The publication of fatwas is one of the fatwa institution initiatives to facilitate the delivery of information as there are a handful of people who have no access to the relevant websites. With fatwa publications, it is easier for the public to understand the law of resolving issues without relying solely on the role of the media. Indirectly, it can increase the level of readability and knowledge of the society more widely and in detail.

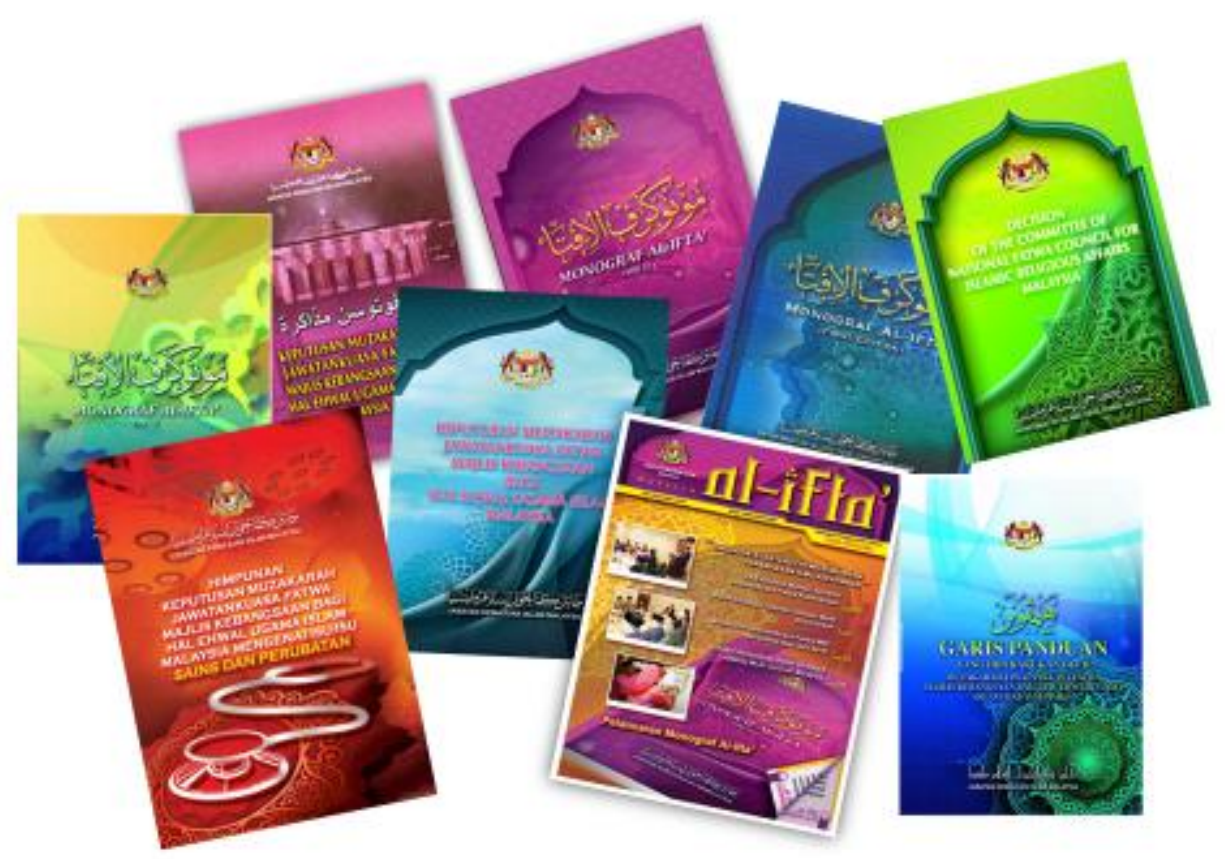

Figure 4: Example of Fatwa Publication

\section{Fatwa Education Seminar / Discourse}

Fatwa Education Seminar/Discourse is one of the important steps that can be taken in spreading the fatwa to the society. Studies have found that some websites have limited functionality as information delivery and discussion are only one-way. In fact, there are few publishing materials that make it difficult for the public to understand the law more widely. Therefore, seminars or discourses are required to enable the delivery of information more effectively and effectively.

Fatwa Education Seminar/Discourse is organized by a fatwa institution in each state aims to expose to the public on matters relating to the fatwa and the procedures involved before 
INTERNATIONAL JOURNAL OF ACADEMIC RESEARCH IN PROGRESSIVE EDUCATION AND DEVELOPMENT

Vol. 7, No. 4, 2018, E-ISSN: 2226-6348 @ 2018 HRMARS

a fatwa is issued. The seminar or discourse is also intended to provide an overview on current issues to avoid confusion in the community's understanding of legal issues while avoiding the public being affected by the views of certain parties. In fact, it also gives the public an opportunity to ask questions or concerns about direct legal rights. Fatwa education Seminar/Discourse is one of the best initiatives in distributing fatwas.
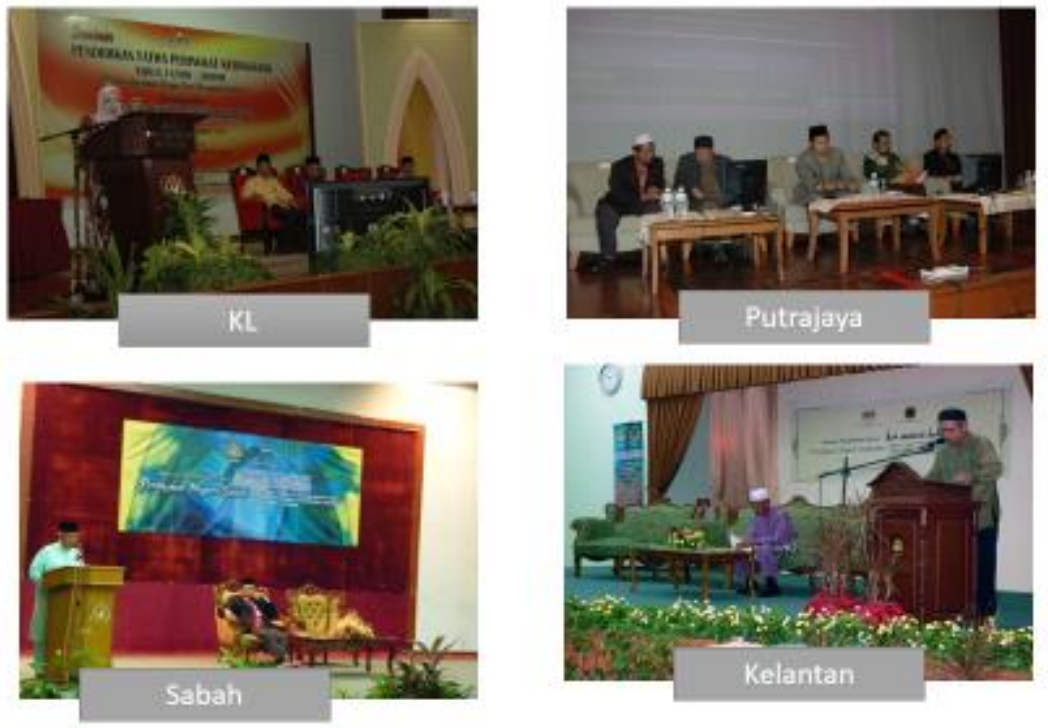

Figure 5: Fatwa Education Seminar/Discourse

\section{CONCLUSION}

In conclusion, fatwa is very important as one of the mediums to educate people about Islamic law especially in Malaysia. Among the mediums used are websites, workshops, seminars, lectures and so on.

\section{ACKNOWLEDGEMENT}

This project was funded by the Special Research Grant Scheme (SRGS) from UniSZA (UniSZA/2017/SRGS/07). We would like to thank UniSZA for the financing provided.

\section{REFERENCES}

Zain, A. M. (2018). Penggunaan Media Sosial dalam Penyebaran Maklumat Fatwa di Wilayah Persekutuan. Selangor: Kolej Universiti Islam Antarabagsa Selangor.

al-Ashqar, U.U. (2009). Fauda al-Iftaq. Jordan: Dar al-Nafais.

Yusof, F.M. (2011). Fatwa Keberkesanannya Memerangi Ajaran Sesat di Malaysia, johor Bahru: Universiti Teknologi Malaysia.

Pusat Penyelidikan Ensiklopedia Malaysia. 1998. Ensiklopedia Islam. Kuala Lumpur. 
INTERNATIONAL JOURNAL OF ACADEMIC RESEARCH IN PROGRESSIVE EDUCATION AND DEVELOPMENT

Vol. 7, No. 4, 2018, E-ISSN: 2226-6348 @ 2018 HRMARS

Mamat, M.N., Mahamood, S.F., Ahmad, M.N., Ismail, A. \& Hariro, Z.. (2008). E-Fatwa Information Management: Sustainance And Enhancement Towards Friendly And Efficient Online Database. World Congress of Muslim Librarian \& Information Scientists 25th -27th November 2008. Kuala Lumpur: Putra World Trade Center.

Alwi, N,H. (2006). Malaysian Fatwa Websites Studies. In International Conference on Information and Communication Technology on the Muslim Worlds 2006.

Gadut, N. (2006). Pengurusan Fatwa di Malaysia. Prinsip Dan Pengurusan Fatwa Di

Negara-Negara Asean, 55-78.

Hassan, W.Z, Alias, J., Muslim, N., Luqman, A. \& Abdullah, S. (2014). Challenges in Fatwa Management in Terengganu, Malaysia, Mediterranean Journal of Social Sciences (5):29.

Khairuldin, W.M.K.F.W. (2010), Metode Fatwa Sheikh 'Ali Jumaa'ah dalam Kitab al-Kalim alTayyib- Fatawa 'Asriyyah. Unpublished Master Thesis. University of Malaya.

Khairuldin, W.M.K.F.W. (2016), Konsep Fatwa dalam Islam. Kuala Terengganu: Penerbit Universiti Sultan Zainal Abidin.

Khairuldin, W. M. K. F. W., Embong, A. H., Anas, W.N.I.W.N., Mohd, H. \& Ismail, D. (2018). The Application of Technology in the Dissemination of Fatwas: A Study on Religious Institutions in Malaysia, International Journal of Civil Engineering and Technology, 9(7), 2018, pp. 1590-1596. 